\title{
Effect of oxygen affinity and molecular weight of HBOCs on cerebral oxygenation and blood pressure in rats
}

\author{
[L'effet de l'affinité pour l'oxygène et du poids moléculaire des TOBH sur l'oxygé- \\ nation et la tension artérielle chez les rats]
}

Gregory M.T. Hare MD PhD, ${ }^{*} \dagger$ Alana Harrington HBsc, ${ }^{*}$ Elaine Liu, Jian Li Wang, ${ }^{*}$ Andrew J. Baker MD, ${ }^{*}$ C. David Mazer $\mathrm{MD}^{*} \dagger$

Purpose: This study assessed the effect of oxygen affinity and molecular weight (MW) of o-raffinose cross-linked hemoglobin based oxygen carriers (HBOCs) on cerebral oxygen delivery and mean arterial blood pressure (MAP) following hemorrhage and resuscitation in rats.

Methods: Isoflurane anesthetized rats ( $n=6-7$ per group) underwent $30 \%$ hemorrhage and resuscitation with an equivalent volume of one of three different HBOCs: I) High $\mathrm{P}_{50}$ Poly o-raffinose hemoglobin (Poly OR-Hb, $\mathrm{P}_{50}=70 \mathrm{mmHg}$ ); 2) High $\mathrm{P}_{50}>128$ Poly OR-Hb (MW > I28 kDa, $\mathrm{P}_{50}=70 \mathrm{mmHg}$ ) and 3) Low $P_{50}>128$ Poly OR-Hb (MW > I28 kDa, $P_{50}=11$ $\mathrm{mmHg}$ ). Hippocampal cerebral tissue oxygen tension, regional cerebral blood flow (rCBF), MAP, total hemoglobin concentration and arterial blood gases were measured. Data analysis by two-way ANOVA and post hoc Tukey tests determined significance $(P<0.05$, mean \pm SD).

Results: Hippocampal tissue oxygen tension increased in all $\mathrm{HBOC}$ groups following resuscitation. The rCBF remained unchanged after $\mathrm{HBOC}$ resuscitation in all groups. Following resuscitation, the peak MAP was higher in the High $\mathrm{P}_{50}$ Poly OR-Hb group ( $152 \pm 13 \mathrm{mmHg}$ ) when compared to either the Low or High $\mathrm{P}_{50}$ large MW, (> I $\left.28 \mathrm{kDa}\right)$ HBOC group (I I \pm $15 \mathrm{mmHg}$ or $127 \pm 18$ respectively, $P<0.05$ for both).

Conclusions: O-raffinose polymerized $\mathrm{HBOC}$, with or without lower MW components, maintained cerebral tissue oxygen delivery following hemorrhage and resuscitation in rats. The higher MW HBOCs showed a decrease in peak MAP, which did not alter oxygen delivery. No significant effect of oxygen affinity on cerebral tissue oxygen tension or blood flow was observed.
Objectif : Évaluer l'effet de l'affinité pour l'oxygène et du poids moléculaire (PM) des transporteurs d'oxygène à base d'hémoglobine (TOBH) avec o-raffinose sur l'apport d'oxygène cérébral et la tension artérielle moyenne (TAM) après une hémorragie et une réanimation chez des rats.

Méthode: Des rats anesthésiés à l'isoflurane ( $n=6-7$ par groupe) ont subi une hémorragie à $30 \%$ et une réanimation avec un volume équivalent de l'un des trois différents TOBH suivants : I) de l'hémoglobine Poly o-raffinose à $P_{50}$ élevé (Poly OR-Hb, $P_{50}$ $=70 \mathrm{mmHg})$; 2) 128 Poly OR-Hb à $P_{50}$ élevé $(P M>128 \mathrm{kDa}$, $\left.P_{50}=70 \mathrm{mmHg}\right)$ et 3) 128 Poly OR-Hb à faible $P_{50}(P M>128$ $k D a, P_{50}=1 / \mathrm{mmHg}$ ). La tension en oxygène du tissu cérébral hippocampique, le débit sanguin cérébral régional (DSCr), la TAM, la concentration d'hémoglobine totale et la gazométrie du sang artériel ont été mesurés. L'analyse de données, par double ANOVA et tests de Tukey ultérieur, ont permis de déterminer la valeur significative $(P<0,05$, moyenne $\pm S D)$.

Résultats : La tension en oxygène du tissu hippocampique s'est accrue dans tous les groupes de TOBH après la réanimation. Le $D S C r$ est resté le même dans tous les groupes après la réanimation avec les TOBH. Après la réanimation, la TAM était plus élevée dans le groupe Poly OR-Hb à $P_{50}$ élevé ( $152 \pm 13 \mathrm{mmHg}$ ) comparé au groupe de TOBH de $P_{50}$ élevé et de grand $P M,(>128 \mathrm{kDa}$ ) (II9 $\pm 15 \mathrm{mmHg}$ ou $127 \pm 18$ respectivement, $P<0,05$ pour les deux).

Conclusion : Les TOBH polymérisés avec o-raffinose, avec ou sans composants de faible PM, ont maintenu l'apport d'oxygène au tissu cérébral après une hémorragie et une réanimation chez des rats. Les TOBH de PM élevé ont montré une baisse de la TAM qui n'a

From the Department of Anesthesia, * St. Michael's Hospital, and the Department of Physiology, $†$ University of Toronto, Toronto, Ontario, Canada.

Address correspondence and reprint requests to: Dr. C. David Mazer, Professor, Department of Anesthesia and Physiology, University of Toronto, St. Michael's Hospital, 30 Bond Street, Toronto, Ontario M5B 1W8, Canada. Phone: 416-864-5825; Fax: 416-864-6014; Email: mazerd@smh.toronto.on.ca

Supported by the Anemia Institute for Research and Education, Canadian Anesthesiologists' Society, Physicians Services Incorporated Foundation, Hemosol LP, St. Michael's Hospital.

Dr. Hare is a recipient of the Bristol-Myers Squibb-CAS Career Scientist Award.

Hemoglobin based oxygen carriers (HBOCs) were generously provided by Hemosol LP. Mississauga, ON, Canada.

Accepted for publication March 29, 2006.

Revision accepted June 26, 2006. 
pas nui à l'apport d'oxygène. Aucun effet significatif de l'affinité pour l'oxygène sur la tension en oxygène du tissu cérébral ou sur le débit sanguin n'a été observé.

A NEMIA and acute blood loss have been associated with increased morbidity and mortality in perioperative patients. ${ }^{1-3}$ Increased mortality has also been associated with transfusion of allogeneic blood, one of the main therapies for resuscitating patients who have experienced severe blood loss. ${ }^{2}$ Availability of a safe and efficacious red blood cell substitute could minimize morbidity and mortality associated with acute blood loss and alleviate adverse outcomes for which allogeneic blood transfusion is found to be an independent predictor. ${ }^{2,4}$ Currently, no blood substitute has been approved for clinical use in North America.

Hemoglobin based oxygen carriers (HBOCs) are one form of red blood cell substitute currently under development. Hemoglobin based oxygen carriers are derived from chemically modified hemoglobins purified from human or animal blood. The predominant modifications are aimed at enlarging the molecular size, extending their intravascular half-life and preventing their extravasation. A number of different products have undergone clinical trials. ${ }^{5-9}$ These products may have associated adverse effects, which include vasoconstriction and/or vasopressor effects. The increase in systemic vasoconstriction has been attributed to increased activity of vasoconstricting molecules including endothelin, ${ }^{10,11}$ and catecholamines $^{12}$ and/or binding of vasodilatory molecules such as nitric oxide by HBOCs. ${ }^{13,14}$ The direct vasoactive effect of different HBOCs appears to be related to the low molecular weight (MW) species in these products. This suggests that small HBOC molecules are more vasoconstricting. ${ }^{15-17}$ Presumably, pronounced vasoconstriction would be disadvantageous because it could limit optimal delivery of oxygen to tissues.

In addition, debate exists as to the optimum oxygen affinity of HBOCs. A number of experimental studies have attempted to determine which oxygen affinity may provide superior tissue oxygen delivery. Some investigators argue that an HBOC possessing a higher oxygen affinity (Low $\mathrm{P}_{50}$ ), would limit excessive tissue oxygen delivery and therefore, minimize hyperoxic vasoconstriction. ${ }^{15,18-20}$ Conversely, a lower oxygen affinity (High $\mathrm{P}_{50}$ ) might ensure optimal ease of oxygen release into the tissue. ${ }^{21}$
The current study was designed to assess the effect of oxygen affinity and MW of one HBOC on cerebral oxygen delivery in a $30 \%$ hemorrhage and resuscitation model in anesthetized rats. This model was designed to approximate moderate hemorrhage and resuscitation in the operating room. Changes in blood pressure and cerebral tissue oxygen tension $\left(\mathrm{P}_{\mathrm{Br}} \mathrm{O}_{2}\right)$ and regional cerebral blood flow $(\mathrm{rCBF})$ were the primary endpoints of interest.

\section{Methods \\ Animal model}

All animal protocols were approved by the Animal Care and Use Committee at St. Michael's Hospital in accordance with the requirements of the Canadian Council on Animal Care. Anesthesia was induced in male Sprague-Dawley rats (Charles River, St. Constant, PQ, Canada), with ketamine/xylazine $100 / 7.5 \mathrm{mg} \cdot \mathrm{kg}^{-1}$ intraperitoneally (Parke-Davis/ Bayer, Toronto, ON, Canada) and maintained with 1\%-2\% isoflurane (Abbott, St. Laurent, PQ, Canada) delivered in $50 \%$ oxygen after intubation. Ventilation was maintained with a pressure-controlled ventilator (Kent Scientific, Litchfield, CT, USA) and was adjusted to achieve normocapnia and normoxia as determined by blood gas analysis (Radiometer ALB 500; London Scientific, London, ON, Canada). The tail artery and vein were cannulated using $24-\mathrm{G}$ catheters to provide vascular access for direct measurement of mean arterial blood pressure (MAP) and blood gases, and to perform hemorrhage and resuscitation. Animals were then placed in a stereotaxic frame (ADI Instruments; Harvard Apparatus, St-Laurent, PQ, Canada), and the scalp incised sagittally. A 5-mm diameter burr hole was performed at the level of the bregma, $2-3 \mathrm{~mm}$ lateral to the sagital sinus, exposing the intact dura.

Combination oxygen sensing microelectrodes, temperature and laser Doppler flow probes (OxyLite and OxyFlow, Oxford Optronix, Oxford, UK) were placed 3-4 mm past the dura into the region of the hippocampus in order to measure both $\mathrm{P}_{\mathrm{Br}} \mathrm{O}_{2}$ and rCBF. A period of $20 \mathrm{~min}$ was used to establish a stable baseline while a heating pad and lamp were used to maintain the brain temperature near $35^{\circ} \mathrm{C}$. This degree of systemic hypothermia was maintained to approximate operating room conditions associated with acute blood loss and crystalloid resuscitation. Brain temperature, $\mathrm{P}_{\mathrm{Br}} \mathrm{O}_{2}, \mathrm{rCBF}$ and MAP were recorded with a computerized data acquisition system (DASYLab 5.6; Kent Scientific). 
TABLE I Characteristics of hemoglobin based oxygen carriers (HBOC)

\begin{tabular}{|c|c|c|c|c|c|c|c|c|c|}
\hline Sample & $\begin{array}{l}P_{50} \\
(m m H g)\end{array}$ & $\begin{array}{l}\text { Viscosity } \\
(c S t)\end{array}$ & $p H$ & $\begin{array}{l}P_{a} \mathrm{CO}_{2} \\
(m m \mathrm{Hg})\end{array}$ & $\begin{array}{l}P_{a} O_{2} \\
(m m H g)\end{array}$ & $\begin{array}{l}\text { Hemoglobin } \\
\left(g \cdot L^{-1}\right)\end{array}$ & $\begin{array}{l}\% \text { Oxygen } \\
\text { saturation }\end{array}$ & $\begin{array}{l}\mathrm{MetHb} \\
(\%)\end{array}$ & $\begin{array}{l}\mathrm{O}_{2} \text { Content } \\
\left(\mathrm{mmol} \cdot \mathrm{L}^{-1}\right)\end{array}$ \\
\hline $\begin{array}{l}\text { High } \mathrm{P}_{50} \\
\text { Poly OR-Hb } \\
\text { High } \mathrm{P}_{50}\end{array}$ & 70 & 1.2 & $7.31 \pm 0.05$ & $1.3 \pm 0.8$ & $209.8 \pm 84.4 \dagger$ & $102 \pm 2 \dagger \ddagger$ & $79.4 \pm 6.1 \ddagger$ & $5.2 \pm 0.6 \dagger \ddagger$ & $4.7 \pm 0.4 \dagger \ddagger$ \\
\hline $\begin{array}{l}>128 \text { Poly } \\
\text { OR-Hb } \\
\text { Low } \mathrm{P}_{50}\end{array}$ & 70 & 2.7 & $7.25 \pm 0.01 \ddagger$ & $1.8 \pm 0.4$ & $346.8 \pm 91.49^{*}$ & $143.3 \pm 1.4^{*}$ & $82.7 \pm 2.1 \ddagger$ & $10.9 \pm 0.7^{*} \ddagger$ & $6.3 \pm 0.3^{*}$ \\
\hline $\begin{array}{l}>128 \text { Poly } \\
\text { OR-Hb }\end{array}$ & 11 & 2.4 & $7.40 \pm 0.09 \dagger$ & $3.9 \pm 5.8$ & $297.79 \pm 31.50$ & $141.6 \pm 2.9^{*}$ & $91.2 \pm 0.4^{*} \dagger$ & $7.2 \pm 0.6^{*} \dagger$ & $7.2 \pm 0.2^{*}$ \\
\hline
\end{tabular}

TABLE II Arterial blood gas and co-oximetry data following hemorrhage and HBOC resuscitation

\begin{tabular}{|c|c|c|c|c|c|c|c|c|}
\hline Time & Sample & $p H$ & $\begin{array}{l}\mathrm{P}_{a} \mathrm{CO}_{2} \\
(\mathrm{mmHg})\end{array}$ & $\begin{array}{l}\mathrm{P}_{a} \mathrm{O}_{2} \\
(m m \mathrm{mg})\end{array}$ & $\begin{array}{l}\text { Hemoglobin } \\
\left(g L^{-1}\right)\end{array}$ & $\%$ Saturation & $\begin{array}{l}\mathrm{MetHb} \\
(\%)\end{array}$ & $\begin{array}{l}\mathrm{O}_{2} \text { Content } \\
\left(\mathrm{mmol} \cdot \mathrm{L}^{-1}\right)\end{array}$ \\
\hline \multicolumn{9}{|c|}{ High $P_{50}$ Poly OR-Hb } \\
\hline $10 \mathrm{~min}$ & Baseline & $7.41 \pm 0.06$ & $35.5 \pm 6.5$ & $145.6 \pm 16.5$ & $127.3 \pm 10.4$ & $99.9 \pm 2.7$ & $0.8 \pm 0.2$ & $7.6 \pm 0.8$ \\
\hline $30 \mathrm{~min}$ & Hemorrhage & $7.36 \pm 0.06$ & $32.7 \pm 7.9$ & $146.8 \pm 32.9$ & $106.5 \pm 9.6^{*}$ & $99.4 \pm 0.9$ & $0.9 \pm 0.3$ & $6.4 \pm 0.6^{*}$ \\
\hline $60 \mathrm{~min}$ & Resuscitation & $7.40 \pm 0.06$ & $39.8 \pm 5.3$ & $194.7 \pm 47.3^{*}$ & $121.2 \pm 11.5$ & $94.7 \pm 3.8^{*}$ & $2.1 \pm 0.5^{*}$ & $6.9 \pm 0.9^{*}$ \\
\hline $90 \mathrm{~min}$ & Resuscitation & $7.44 \pm 0.05$ & $36.9 \pm 7.8$ & $189.5 \pm 41.6^{*}$ & $118.5 \pm 5.1$ & $94.9 \pm 4.3^{*}$ & $2.4 \pm 0.9^{*}$ & $6.6 \pm 0.4^{*}$ \\
\hline \multicolumn{9}{|c|}{ High $P_{50}>128$ Poly OR $-\mathrm{Hb}$} \\
\hline $10 \mathrm{~min}$ & Baseline & $7.36 \pm 0.02$ & $44.3 \pm 4.34$ & $166.2 \pm 12.6$ & $126.5 \pm 2.3$ & $100.0 \pm 0.0$ & $1.1 \pm 0.1$ & $7.6 \pm 0.1$ \\
\hline $30 \mathrm{~min}$ & Hemorrhage & $7.36 \pm 0.03$ & $35.4 \pm 3.1$ & $183.7 \pm 25.4$ & $101.0 \pm 13.0^{*}$ & $98.8 \pm 3.0$ & $0.9 \pm 0.4$ & $5.9 \pm 1.0^{*}$ \\
\hline $60 \mathrm{~min}$ & Resuscitation & $7.37 \pm 0.04$ & $42.0 \pm 4.6$ & $254.2 \pm 50.8^{*} \dagger$ & $125.5 \pm 10.2$ & $95.2 \pm 1.3^{*}$ & $4.5 \pm 0.6^{*}+\$$ & $6.9 \pm 0.6$ \\
\hline $90 \mathrm{~min}$ & Resuscitation & $7.40 \pm 0.04$ & $37.7 \pm 5.1$ & $243.8 \pm 59.2^{*}$ & $121.8 \pm 19.5$ & $95.3 \pm 1.8^{*}$ & $4.8 \pm 1.3^{*}+\$$ & $6.7 \pm 1.2$ \\
\hline \multicolumn{9}{|c|}{ Low $P_{50}>128$ Poly OR $-\mathrm{Hb}$} \\
\hline $10 \mathrm{~min}$ & Baseline & $7.42 \pm 0.04$ & $37.2 \pm 7.2$ & $196.6 \pm 38.0$ & $125.5 \pm 9.5$ & $100.0 \pm 0.0$ & $1.1 \pm 0.1$ & $7.5 \pm 0.6$ \\
\hline $30 \mathrm{~min}$ & Hemorrhage & $7.39 \pm 0.06$ & $33.9 \pm 11.3$ & $185.5 \pm 31.9$ & $109.0 \pm 6.9^{*}$ & $100.0 \pm 0.0$ & $1.0 \pm 0.2$ & $6.5 \pm 0.4^{*}$ \\
\hline $60 \mathrm{~min}$ & Resuscitation & $7.39 \pm 0.05$ & $40.0 \pm 8.1$ & $234.7 \pm 41.7$ & $122.6 \pm 7.7$ & $98.5 \pm 0.7^{*} \dagger \ddagger$ & $3.3 \pm 0.6^{*} \dagger \ddagger$ & $7.1 \pm 0.4$ \\
\hline $90 \mathrm{~min}$ & Resuscitation & $7.43 \pm 0.04$ & $35.6 \pm 6.8$ & $230.6 \pm 48.6$ & $118.6 \pm 13.5$ & $98.8 \pm 0.7^{*} \dagger \ddagger$ & $3.6 \pm 0.9^{*} \dagger \ddagger$ & $6.8 \pm 0.8^{*}$ \\
\hline
\end{tabular}

${ }^{\star} P<0.05$ compared to baseline within each group; $\dagger P<0.05$ vs High $\mathrm{P}_{50}$ Poly OR-Hb, at the same sample time; $\ddagger P<0.05$ vs High $\mathrm{P}_{50}>$ 128 Poly OR-Hb, at the same sample time; $\$ P<0.05$ vs Low $\mathrm{P}_{50}>128$ PolyOR-Hb, at the same sample time.

\section{Hemoglobin based oxygen carriers}

Three different HBOCs were prepared by a process of pasteurization, chromatographic purification, viral filtration, and o-raffinose cross-linking of hemoglobin from out-dated human blood collected from Food and Drug Administration-approved collection sites ( $>42$ days from donation). Characteristics of these HBOCs are outlined in Table I. The first HBOC consisted of polymeric o-raffinose cross-linked hemoglobin raffimer (Poly OR-Hb) with a heterogeneous MW composition $(\sim 55 \% \leq 128 \mathrm{kDa})$ and a High $\mathrm{P}_{50}$ (low oxygen affinity), (High $\mathrm{P}_{50}$ Poly OR-Hb, $\mathrm{P}_{50}=70$ $\mathrm{mmHg}){ }^{22}$ The other two HBOCs consisted of Poly OR-Hb prepared essentially entirely with a $\mathrm{MW}$ of $>$ $128 \mathrm{kDa}(5-10 \% \leq 128 \mathrm{kDa})$. Two different HBOCs were utilized, one which had a low oxygen affinity $\left(\right.$ High $\mathrm{P}_{50}>128$ Poly OR-Hb, MW > $128 \mathrm{kDa}, \mathrm{P}_{50}=$ $70 \mathrm{mmHg}$ ) and one which had a high oxygen affinity (Low $\mathrm{P}_{50}>128$ Poly OR-Hb, MW $>128 \mathrm{kDa}, \mathrm{P}_{50}=$
$11 \mathrm{mmHg}$ ). The MW distributions of the $>128 \mathrm{kDa}$ HBOC products were similar.

\section{Hemorrhage and resuscitation protocol}

Three different groups of animals were studied in which one of the three HBOC solutions was used for resuscitation ( $n=6-7$ rats per group). Each group underwent a controlled hemorrhage of $30 \%$ of the estimated blood volume at a constant rate over a period of ten minutes by using a programmable “push-pull” pump (PHD 2000; Harvard Apparatus). After $30 \mathrm{~min}$ of hypovolemia, each animal was resuscitated with an equal volume of High $\mathrm{P}_{50}$ Poly OR-Hb, High $\mathrm{P}_{50}>128$ Poly OR-Hb or Low $\mathrm{P}_{50}>128$ Poly $\mathrm{OR}-\mathrm{Hb}$ infused over ten minutes. After completion of fluid resuscitation, all variables were recorded for an additional $90 \mathrm{~min}$ before the animal was sacrificed by anesthetic overdose (ketamine $100 \mathrm{mg}$ iv; ParkeDavis). For each group, arterial blood gas analysis 
(Radiometer ALB 500) and co-oximetry (Radiometer OSM 3, London Scientific) were measured at baseline (ten minutes), after hemorrhage $(30 \mathrm{~min})$ and after fluid resuscitation (60 and $90 \mathrm{~min}$ ). Brain temperature, $\mathrm{P}_{\mathrm{Br}} \mathrm{O}_{2}$ and $\mathrm{rCBF}$ measurements from the probe were recorded at 30-sec intervals for each experimental animal.

\section{Data analysis}

Individual laser Doppler flowmetry measurements were normalized to the baseline values derived from averaging the data over the first $20 \mathrm{~min}$. All data were assessed with SAS (SAS Institute Inc., Cary, NC, USA). Data were analyzed using a two-way analysis of variance (ANOVA) at ten, 30, 60 and $90 \mathrm{~min}$ and post-hoc Tukey tests were performed when appropriate. A one-way ANOVA was utilized to compare the maximum blood pressure response to HBOC resuscitation between the three treatments. All data are expressed as mean \pm SD and significance assigned at a value of $P<0.05$.

\section{Results}

\section{Poly-hemoglobin raffimer solutions}

Prior to infusion into the animals, all $\mathrm{HBOC}$ solutions were analyzed and found to be within the acceptable specifications. Hemoglobin based oxygen carriers were iso-oncotic with plasma. The hemoglobin concentration and calculated oxygen content of both high MW hemoglobin solutions were comparable, but significantly higher than the HBOC containing low MW components ((High $\mathrm{P}_{50}$ Poly OR-Hb) $\mathrm{P}<$ 0.05 , Table I). The oxygen saturation of the Low $\mathrm{P}_{50}$ HBOC $(91.2 \pm 0.4 \%)$ was higher than that of both High $P_{50}$ solutions $(82.7 \pm 2.1$ and $79.4 \pm 6.1 \%, P<$ 0.05 for both, Table I). The initial methemoglobin concentration for each HBOC solution ranged from $5.2 \pm 0.6$ to $10.9 \pm 0.7 \%$ (Table I). The $\mathrm{pH}$ of High $\mathrm{P}_{50}>128$ Poly OR-Hb was slightly lower that of the Low $\mathrm{P}_{50}>128$ Poly OR-Hb solution $(7.25 \pm 0.01 v s$ $7.40 \pm 0.09, P<0.05$, Table I). The $\mathrm{P}_{\mathrm{a}} \mathrm{O}_{2}$ of the High $\mathrm{P}_{50}>128$ Poly OR-Hb was significantly higher than that of HBOC containing low MW components. The Low and High $\mathrm{P}_{50}>128$ Poly OR-Hb solutions had higher viscosity than High $\mathrm{P}_{50}$ Poly OR-Hb (Table I). All other initial measured values did not differ between groups.

\section{Hemorrhage resuscitation experiments}

No significant differences were found between baseline blood gas or co-oximetry values for any of the three experimental groups at baseline (Table II). Arterial blood gas analysis demonstrated no difference within or between groups with respect to $\mathrm{pH}$ and $\mathrm{P}_{\mathrm{a}} \mathrm{CO}_{2}$ at any time (Table II). A significantly higher $\mathrm{P}_{\mathrm{a}} \mathrm{O}_{2}$ was observed at $60 \mathrm{~min}$ in the group resuscitated with High $\mathrm{P}_{50}>128$ Poly OR-Hb, relative to the High $\mathrm{P}_{50}$ Poly OR-Hb (Table II, $P<0.05$ ). Following hemorrhage, there was a comparable reduction in hemoglobin concentration in all groups, relative to baseline (Table II, $P<0.05$ ). Following resuscitation, the hemoglobin concentration returned to baseline in all groups without any significant differences between groups (Table II). Arterial blood oxygen content paralleled the hemoglobin concentration values. There were no differences in oxygen content between groups at any time. Oxygen saturation decreased significantly in all groups following HBOC resuscitation. The post-resuscitation oxygen saturation values were higher in the Low $\mathrm{P}_{50}>128$ Poly OR-Hb group relative to both High $\mathrm{P}_{50}$ HBOC groups $(P<0.05$ for both, Table II). Methemoglobin concentrations increased significantly in all groups following resuscitation. The methemoglobin levels were highest in the High $\mathrm{P}_{50}>$ 128 Poly OR-Hb group $(4.8 \pm 1.3 \%)$, next highest in the Low $\mathrm{P}_{50}>128$ Poly OR-Hb group $(3.6 \pm 0.9 \%)$ and lowest in the High $\mathrm{P}_{50}$ Poly OR-Hb group (2.4 \pm $0.9 \%)$, (Table II). These relative values corresponded to the differences in starting methemoglobin concentrations in the different HBOC solutions (Table I).

No differences in brain temperatures were recorded between groups at any time. After HBOC resuscitation, brain temperatures were $33.3 \pm 1.2,34.3 \pm 0.6$ and $34.1 \pm 0.7^{\circ} \mathrm{C}$ in the low MW, and either high MW HBOC groups, respectively. Baseline MAP values were not different between groups $(81.5 \pm 5.0$, $76.2 \pm 9.5$ and $70.4 \pm 12.9 \mathrm{mmHg}$ ). The peak MAP was significantly higher in the High $\mathrm{P}_{50}$ Poly OR-Hb $(152 \pm 13 \mathrm{mmHg})$ when compared to either high MW HBOC groups $(119 \pm 15$ and $127 \pm 18 \mathrm{mmHg}$, Low and High $\mathrm{P}_{50}>128$ Poly OR-Hb respectively; $P$ $<0.05$, Figure). After the peak, MAP values remained elevated in all groups relative to baseline $(P<0.05$, Figure). Following 30\% hemorrhage, there was a transient drop in tissue oxygen tension and $\mathrm{rCBF}$ for all groups. These values all recovered to baseline levels prior to fluid resuscitation with HBOC. In all groups, the hippocampal tissue oxygen tension increased above baseline values after resuscitation, but no significant differences were observed between groups. Following resuscitation, the rCBF remained near baseline in all groups without any significant differences between groups.

\section{Discussion}

This study demonstrated the maintenance of adequate 


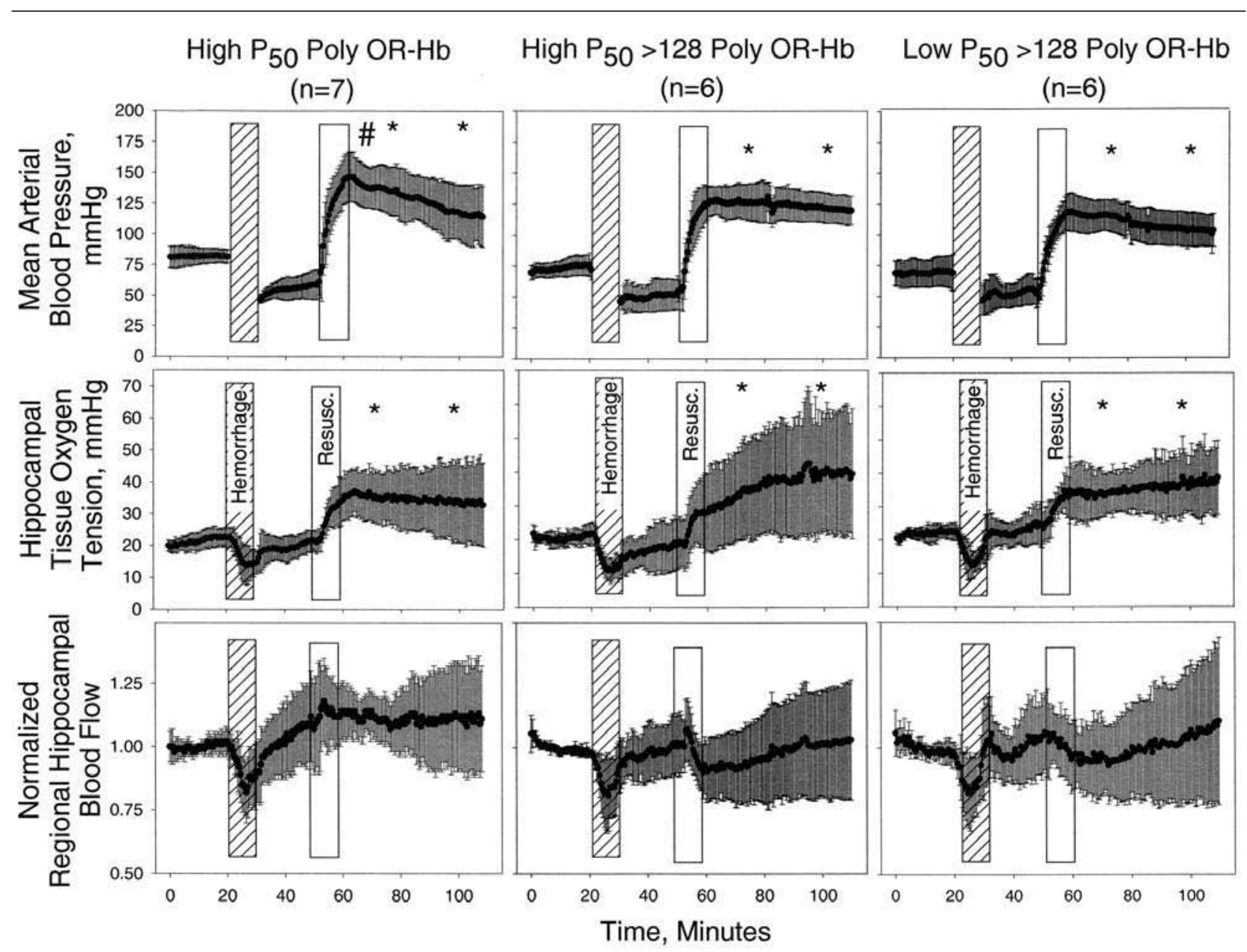

FIGURE Data from all animals for mean arterial blood pressure (MAP), cerebral tissue oxygen tension and regional cerebral blood flow, presented as mean $\pm \mathrm{SD}$, before during and after hemorrhage (hatched box) and hemoglobin based oxygen carrier (HBOC) resuscitation (open box). The peak MAP was greater in the High $\mathrm{P}_{50}$ Poly o-raffinose hemoglobin (Poly $\mathrm{OR}-\mathrm{Hb}$ ) group when compared to both High and Low $\mathrm{P}_{50}>128$ Poly OR-Hb groups. After HBOC resuscitation hippocampal tissue oxygen tension increased relative to baseline in all three HBOC groups. The regional hippocampal blood flow was not different from baseline after resuscitation with all three HBOCs. $\# P<0.05$ between groups; ${ }^{*}<0.05$ compared to baseline.

local $\mathrm{P}_{\mathrm{Br}} \mathrm{O}_{2}$ following hemorrhage and resuscitation with o-raffinose polymerized hemoglobin, in the presence of a systemic hypertensive response. Neither the MW nor oxygen affinity of Poly OR-Hb affected $\mathrm{P}_{\mathrm{Br}} \mathrm{O}_{2}$. However, a reduction in peak MAP was associated with an increase in the HBOC MW. This reduction in vasopressor effect occurred despite a higher initial hemoglobin concentration and higher viscosity in the high MW HBOC groups. These data suggest that the lower MW components of Poly OR-Hb contribute to the vasopressor effect associated with $\mathrm{HBOC}$ infusion, but do not account for all vasoactivity of these HBOCs. Despite the effect on MAP, $\mathrm{P}_{\mathrm{Br}} \mathrm{O}_{2}$ increased comparably following resuscitation with all HBOC compounds. Therefore, cerebral tissue oxygen delivery was maintained in all treatment groups.

In this study, the oxygen affinity of the HBOC solutions did not significantly affect cerebral tissue oxygen delivery. Therefore, no advantage of manipulating $\mathrm{P}_{50}$, within this range, was identified. The increase in $\mathrm{P}_{\mathrm{Br}} \mathrm{O}_{2}$ was achieved without any increase in $\mathrm{rCBF}$ for all $\mathrm{HBOC}$ solutions suggesting that the ability of each HBOC to deliver oxygen to the brain was not impaired. Similar results have previously been measured following normovolemic hemodilution with an HBOC. ${ }^{23}$ In that study, hemodilution with pen- 
tastarch resulted in a significant increase in $\mathrm{rCBF}$ with no increase in $\mathrm{P}_{\mathrm{Br}} \mathrm{O}_{2}$, whereas with $\mathrm{HBOC}$ hemodilution, $\mathrm{P}_{\mathrm{Br}} \mathrm{O}_{2}$ increased with no change in $\mathrm{rCBF}$. This balance of maintained cerebral oxygen delivery without cerebral hyperemia could be beneficial in limiting reperfusion injury and in other clinical settings in which increases in cerebral blood flow may be potentially harmful.

The increase in systemic blood pressure after HBOC administration has been attributed to increased activity of vasoconstricting molecules including endothelin, ${ }^{11,24}$ and catecholamines, ${ }^{12}$ and/or binding of vasodilatory molecules such as nitric oxide by HBOCs. ${ }^{13,14,25}$ The increase in vascular tone could also be a direct compensatory effect of increased oxygen delivery to tissues at the microvascular level. In addition to direct vasoconstriction effect, the increase in blood pressure could also be due to an increase in intravascular volume secondary to increased colloid oncotic pressure. However, this effect should have been uniform, as all tested HBOCs had similar colloid osmotic pressures. The direct vasoactive effect of different HBOCs appears to be inversely related to their MW which suggests that small molecules are more vasoconstricting. ${ }^{15-17}$ Clinical and experimental studies suggest that the order of vasoreactivity is highest for the smaller MW HBOCs including diaspirin cross-linked hemoglobin, moderate for polymerized hemoglobins which contain a portion of small MW hemoglobins, and lowest for surface modified hemoglobins that have higher MWs. ${ }^{26}$ The current study supports this hypothesis within a single group of chemically modified HBOCs.

This study was designed to compare the effects of three different HBOCs on cerebral oxygen delivery. A direct comparison of resuscitation with HBOCs to crystalloid or colloid was not performed. However, in previous studies using similar experimental techniques, hemodilution or hemorrhage and resuscitation with normal saline and pentastarch maintained $\mathrm{P}_{\mathrm{Br}} \mathrm{O}_{2}$ and significantly increased $\mathrm{rCBF}^{23,27}$ In one study, resuscitation with $5 \%$ albumin resulted in an increase in both parameters. ${ }^{27}$ The main differences between these results and those obtained with HBOC resuscitation are that $\mathrm{MAP}$ and $\mathrm{P}_{\mathrm{Br}} \mathrm{O}_{2}$ increase to a larger degree while $\mathrm{rCBF}$ remains unchanged following $\mathrm{HBOC}$ resuscitation.

Hemodilution with HBOCs has also been utilized to determine if oxygen affinity affects the delivery of oxygen to tissue. The $\mathrm{P}_{50}$ of human blood is 28 $\mathrm{mmHg}$. An $\mathrm{HBOC}$ with a higher oxygen affinity $\left(\mathrm{P}_{50}\right.$ $<28 \mathrm{mmHg}$ ) would be expected to bind oxygen more tightly and therefore have improved oxygen uptake and provide a greater oxygen reservoir. A lower affinity HBOC $\left(\mathrm{P}_{50}>28 \mathrm{mmHg}\right)$ could be expected to have an increased capacity to unload oxygen at the tissue. ${ }^{28}$ A number of experimental studies have compared the relative ability of $\mathrm{HBOCs}$ with different $\mathrm{P}_{50}$ values to deliver oxygen to tissue. Some of these studies have demonstrated that high affinity HBOCs maintained better tissue oxygen delivery. ${ }^{15,20,29}$ Conversely, other experimental studies demonstrate that low oxygen affinity HBOCs were superior at delivering oxygen to tissues. ${ }^{21}$ Other investigators were unable to demonstrate any difference in oxygen delivery when comparing HBOCs with different oxygen affinities. ${ }^{18,30,31}$ Overall, the existing data do not provide conclusive evidence for the optimal HBOC oxygen affinity for tissue oxygen delivery. One limitation of most of these studies is that identical HBOC compounds with differing oxygen affinities have not been assessed. Therefore, the confounding effects of different HBOC structures and properties may have contributed. One study in which the same HBOC structure was modified to produce a similar HBOC with three different oxygen affinities $\left(\mathrm{P}_{50}\right.$ of 9,16 and $30 \mathrm{mmHg}$ ) demonstrated that the highest affinity HBOC $\left(\mathrm{P}_{50} 9 \mathrm{mmHg}\right)$ had reduced oxygen delivery, while an HBOC with a slightly lower oxygen affinity $\left(\mathrm{P}_{50} 16 \mathrm{mmHg}\right)$ may have exhibited more favourable oxygen delivery characteristics. ${ }^{19}$ Our results do not provide evidence of superior oxygen delivery with either low or high oxygen affinity HBOCs. This may be due to the fact that the volume of hemorrhage and resuscitation was limited to $30 \%$.

A large number of experimental studies have demonstrated that resuscitation with different HBOCs has the capacity to restore MAP, ${ }^{32,33}$ and improve tissue blood flow, ${ }^{34}$ capillary density ${ }^{33,35}$ and tissue oxygen tension. ${ }^{26,35}$ These positive effects reverse the base deficit, ${ }^{32,36}$ reduce lactate production ${ }^{15}$ and decrease acute mortality. ${ }^{15,37,38}$ Improved outcomes in one experimental study were attributed to an $\mathrm{HBOC}$ with lower vasoactive potential and a higher oxygen affinity. ${ }^{15}$ Resuscitation with HBOCs has been demonstrated to restore cerebral blood flow and $\mathrm{P}_{\mathrm{Br}} \mathrm{O}_{2} 34,39$ However, these positive experimental results must be interpreted with caution because one clinical study was stopped prematurely due to higher mortality in the HBOC group. ${ }^{40}$ Further experimental studies are required to assess the value of $\mathrm{HBOC}$ in hemorrhage resuscitation before they can safely be utilized to resuscitate patients from hypovolemic shock.

There are several limitations to this study. It was designed to model a hemorrhage that occurs in the operating room, so the results may not be directly 
applicable to severe and sudden hemorrhage that occurs in conscious patients following trauma. The chemical properties of the starting HBOC solutions were different in some measurements. The lower MW HBOC had a necessarily lower hemoglobin concentration relative to both high MW solutions so that all three solutions were iso-oncotic with plasma. However, this would not account for the larger increase in MAP observed in the low MW group. The $\mathrm{pH}$ of the High $\mathrm{P}_{50}>128$ Poly OR-Hb $(7.25 \pm 0.01)$ was slightly lower than that of the High $\mathrm{P}_{50}$ Poly OR$\mathrm{Hb}(7.31 \pm 0.05)$. However, immediately after resuscitation the $\mathrm{pH}$ of the first blood sample was similar in both groups $(7.37 \pm 0.04$ vs $7.40 \pm 0.06)$. Therefore, no difference in the oxygen affinity would be expected in vivo. Similarly, differences in the oxygen content of the three HBOCs in vitro did not result in any significant difference in the post-resuscitation blood oxygen content which was similar in all groups (Table II). Although the methemoglobin concentrations of the three HBOC solutions were different, this did not affect oxygen delivery to the brain. Changes in blood viscosity are known to affect vascular tone. In the current study, one HBOC group had a viscosity of $1.2 \mathrm{cSt}$ while the other two were closely matched at 2.7 and $2.4 \mathrm{cSt}$, and similar to whole blood viscosity $(\sim 3 \mathrm{cSt})$. At a $30 \%$ blood replacement ratio this would result in a maximum difference in viscosity of 0.5 fold. Cabrales et al. have demonstrated that a threefold increase in blood viscosity results in about a $30 \%$ increase in hamster skin fold blood flow. ${ }^{41}$ If we assume a similar degree of response in our model then a 0.5 fold change in viscosity would be expected to produce a $5 \%$ change in blood flow. This small effect is not likely to be experimentally or clinically significant.

All baseline values demonstrated relatively small standard deviations. However, there was an increase in variability following hemorrhage and $\mathrm{HBOC}$ resuscitation. This variability is in keeping with other published reports in rat $^{23,42}$ and demonstrates significant individual variation in the response to resuscitation. Despite this variation, statistically significant increases in brain tissue oxygen tension were observed after resuscitation with each HBOC. This study did not assess cerebral effects at the cellular level.

In summary, adequate oxygen delivery to cerebral tissue was demonstrated for three different HBOC solutions following 30\% hemorrhage and resuscitation. Resuscitation with higher MW HBOCs (> 128 $\mathrm{kDa}$ ) was associated with a reduction in the peak increase in MAP. This did not impair the ability of the HBOCs to maintain $\mathrm{P}_{\mathrm{Br}} \mathrm{O}_{2}$. No effect of oxygen affin- ity was observed, possibly due to the limited extent of hemorrhage and resuscitation (30\%).

\section{Acknowledgements}

The authors gratefully acknowledge Mr. R. Qu for his technical assistance and Mr. Colin Kay for performing the statistical analysis.

\section{References}

1 Carson JL, Poses RM, Spence RK, Bonavita G. Severity of anaemia and operative mortality and morbidity. Lancet 1988; 1: 727-9.

2 Dunne JR, Malone D, Tracy JK, Gannon C, Napolitano $L M$. Perioperative anemia: an independent risk factor for infection, mortality, and resource utilization in surgery. J Surg Res 2002; 102: 237-44.

3 Jonas RA, Wypij D, Roth SJ, et al. The influence of hemodilution on outcome after hypothermic cardiopulmonary bypass: results of a randomized trial in infants. J Thorac Cardiovasc Surg 2003; 126: 1765-74.

4 Malone DL, Dunne J, Tracy JK, Putnam AT, Scalea TM, Napolitano LM. Blood transfusion, independent of shock severity, is associated with worse outcome in trauma. J Trauma 2003; 54: 898-905.

5 Gould SA, Moore EE, Hoyt DB, et al. The first randomized trial of human polymerized hemoglobin as a blood substitute in acute trauma and emergent surgery. J Am Coll Surg 1998; 187: 113-20.

6 Levy JH, Goodnough LT, Greilich PE, et al. Polymerized bovine hemoglobin solution as a replacement for allogeneic red blood cell transfusion after cardiac surgery: results of a randomized, double-blind trial. J Thorac Cardiovasc Surg 2002; 124: 35-42.

7 Cheng DC, Mazer CD, Martineau R, et al. A phase II dose-response study of hemoglobin raffimer (Hemolink) in elective coronary artery bypass surgery. J Thorac Cardiovasc Surg 2004; 127: 79-86.

8 Greenburg AG, Kim HW. Use of an oxygen therapeutic as an adjunct to intraoperative autologous donation to reduce transfusion requirements in patients undergoing coronary artery bypass graft surgery. J Am Coll Surg 2004; 198: 373-83.

9 Sloan EP, Koenigsberg M, Gens D, et al. Diaspirin cross-linked hemoglobin (DCLHb) in the treatment of severe traumatic hemorrhagic shock: a randomized controlled efficacy trial. JAMA 1999; 282: 1857-64.

10 Gulati A, Singh R, Chung SM, Sen AP. Role of endothelin-converting enzyme in the systemic hemodynamics and regional circulatory effects of proendothelin- 1 (1-38) and diaspirin cross-linked hemoglobin in rats. J Lab Clin Med 1995; 126: 559-70.

11 Saxena R, Wijnhoud AD, Man in 't Veld AJ, et al. Effect of diaspirin cross-linked hemoglobin on endo- 
thelin- 1 and blood pressure in acute ischemic stroke in man. J Hypertens 1998; 16: 1459-65.

12 Gulati A, Rebello Sen AP. Role of adrenergic mechanisms in the pressor effect of diaspirin cross-linked hemoglobin. J Lab Clin Med 1994; 124: 125-33.

13 Asano $\Upsilon$, Koebler RC, Ulatowski JA, Traystman RJ, Bucci E. Effect of cross-linked hemoglobin transfusion on endothelial-dependent dilation in cat pial arterioles. Am J Physiol 1998; 275: H1313-21.

14 von Dobschuetz E, Hutter J, Hoffmann T, Messmer K. Recombinant human hemoglobin with reduced nitric oxide-scavenging capacity restores effectively pancreatic microcirculatory disorders in hemorrhagic shock. Anesthesiology 2004; 100: 1484-90.

15 Winslow RM, Gonzales A, Gonzales $M L$, et al. Vascular resistance and the efficacy of red cell substitutes in a rat hemorrhage model. J Appl Physiol 1998; 85: 9931003.

16 Lieberthal W, Fubro R, Freedman JE, Toolan G, Loscalzo $J$, Valeri CR. O-raffinose cross-linking markedly reduces systemic and renal vasoconstrictor effects of unmodified human hemoglobin. J Pharmacol Exp Ther 1999; 288: 1278-87.

17 Conover CD, Linberg $R$, Shum KL, Shorr RG. The ability of polyethylene glycol conjugated bovine hemoglobin (PEG-Hb) to adequately deliver oxygen in both exchange transfusion and top-loaded rat models. Artif Cells Blood Substit Immobil Biotechnol 1999; 27 : 93-107.

18 Vaslef SN, Kaminski BJ, Talarico TL. Oxygen transport dynamics of acellular hemoglobin solutions in an isovolemic hemodilution model in swine. J Trauma 2001; 51: 1153-60.

19 Sakai H, Tsai AG, Roblfs RJ, et al. Microvascular responses to hemodilution with $\mathrm{Hb}$ vesicles as red blood cell substitutes: influence of $\mathrm{O} 2$ affinity. Am J Physiol 1999; 276: H553-62.

20 Cabrales P, Sakai H, Tsai AG, Takeoka S, Tsuchida E, Intaglietta $M$. Oxygen transport by low and normal P50 hemoglobin-vessicles in extreme hemodilution. Am J Physiol 2004; 288: H1885-92.

21 Richardson RS, Tagore K, Haseler LJ, Jordan M, Wagner PD. Increased VO2 max with right-shifted $\mathrm{Hb}-\mathrm{O} 2$ dissociation curve at a constant $\mathrm{O} 2$ delivery in dog muscle in situ. J Appl Physiol 1998; 84: 9951002.

22 Carmichael FJ, Ali AC, Campbell JA, et al. A phase I study of oxidized raffinose cross-linked human hemoglobin. Crit Care Med 2000; 28: 2283-92.

23 Hare GMT, Hum KM, Kim SY, Barr A, Baker AJ, Mazer $C D$. Increased cerebral tissue oxygen tension after extensive hemodilution with a hemoglobin-based oxygen carrier. Anesth Analg 2004; 99: 528-35.
24 Gulati A, Sen AP, Sharma AC, Singh G. Role of ET and NO in resuscitative effect of diaspirin cross-linked hemoglobin after hemorrhage in rat. Am J Physiol 1997; 273: H827-36.

25 Freas W, Llave R, Jing M, Hart J, McQuillan P, Muldoon S. Contractile effects of diaspirin cross-linked hemoglobin (DCLHb) on isolated porcine blood vessels. J Lab Clin Med 1995; 125: 762-7.

26 Drobin D, Kjellstrom BT, Malm E, et al. Hemodynamic response and oxygen transport in pigs resuscitated with maleimide-polyethylene glycol-modified hemoglobin (MP4). J Appl Physiol 2004; 96: 1843-53.

27 Hare GM, Mazer CD, Liu E, Qu R, Sikich N, Baker $A J$. Resuscitation with albumin improves cerebral oxygenation following hemorrhage in rats. J Neurotrauma 2004; 9: 1280.

28 Kavdia M, Pittman RN, Popel AS. Theoretical analysis of effects of blood substitute affinity and cooperativity on organ oxygen transport. J Appl Physiol 2002; 93: 2122-8.

29 Conover CD, Malatesta P, Lejeune L, Chang CL, Shorr $R G$. The effects of hemodilution with polyethylene glycol bovine hemoglobin (PEG-Hb) in a conscious porcine model. J Invest Med 1996; 44: 238-46.

30 Rosen AL, Gould S, Sehgal LR, et al. Cardiac output response to extreme hemodilution with hemoglobin solutions of various P50 values. Crit Care Med 1979; 7: 380-4.

31 Pittman RN, Miller KB, Tait PH. Effect of hemoglobin solutions as hemodiluents on capillary oxygen tension. Adv Exp Med Biol 2003; 510: 83-8.

32 Driessen B, Jahr JS, Lurie F, Golkaryeh MS, Gunther $R A$. Arterial oxygenation and oxygen delivery after hemoglobin-based oxygen carrier infusion in canine hypovolemic shock: a dose-response study. Crit Care Med 2003; 31: 1771-9.

33 von Dobschuetz E, Hoffmann T, Messmer K. Diaspirin cross-linked hemoglobin effectively restores pancreatic microcirculatory failure in hemorrhagic shock. Anesthesiology 1999; 91: 1754-62.

34 Chappell JE, McBride WJ, Shackford SR. Diaspirin cross-linked hemoglobin resuscitation improves cerebral perfusion after head injury and shock. J Trauma 1996; 41: 781-8.

35 Wettstein R, Tsai AG, Erni D, Winslow RM, Intaglietta $M$. Resuscitation with polyethylene glycol-modified human hemoglobin improves microcirculatory blood flow and tissue oxygenation after hemorrhagic shock in awake hamsters. Crit Care Med 2003; 31: 1824-30.

36 Kerger H, Tsai AG, Saltzman DJ, Winslow RM, Intaglietta $M$. Fluid resuscitation with $\mathrm{O} 2$ vs. non-O2 carriers after $2 \mathrm{~h}$ of hemorrhagic shock in conscious hamsters. Am J Physiol 1997; 272: H525-37. 
37 Katz LM, Manning JE, McCurdy S, et al. HBOC-201 improves survival in a swine model of hemorrhagic shock and liver injury. Resuscitation 2002; 54: 77-87.

38 Maxwell RA, Gibson JB, Fabian TC, Proctor KG. Resuscitation of severe chest trauma with four different hemoglobin-based oxygen-carrying solutions. J Trauma 2000; 49: 200-9.

39 Manley GT, Hemphill JC, Morabito D, et al. Smallvolume resuscitation with the hemoglobin substitute HBOC-201: effect on brain tissue oxygenation. Advanc Exp Med Biol 2003; 530: 311-7.

40 Saxena R, Wijnhoud AD, Carton H, et al. Controlled safety study of a hemoglobin-based oxygen carrier, DCLHb, in acute ischemic stroke. Stroke 1999; 30: 993-6.

41 Cabrales $P$, Intaglietta $M$, Tsai AG. Increase plasma viscosity sustains microcirculation after resuscitation from hemorrhagic shock and continuous bleeding. Shock 2005; 23: 549-55.

42 Shen H, Greene AS, Stein EA, Hudetz AG. Functional cerebral hyperemia is unaffected by isovolemic hemodilution. Anesthesiology 2002; 96: 142-7. 